\title{
EVALUATION OF THE LEVEL OF SHADOW ECONOMY IN LITHUANIAN REGIONS
}

\author{
Rita REMEIKIENE $\dot{1}^{1^{*}}$, Ligita GASPARE்NIENE ${ }^{2}$, Özlem YORULMAZ ${ }^{3}$, \\ Martin SCHIEG ${ }^{4}$, Andrius STASIUKYNAS ${ }^{5}$ \\ ${ }^{1,2}$ Law Faculty, Vilnius University, Vilnius, Lithuania \\ ${ }^{3}$ Department of Econometrics, Faculty of Economics, Istanbul University, Istanbul, Turkey \\ ${ }^{4}$ Technical University of Munich, Munich, Germany \\ ${ }^{5}$ Business School, Kazimieras Simonavičius University, Vilnius, Lithuania
}

Received 11 November 2020; accepted 07 May 2021

\begin{abstract}
The article addresses a topical issue which is extremely relevant in crisis periods - evaluation of the level of the shadow economy in all Lithuanian regions. By applying the MIMIC modelling, three equations were developed for three different periods: economic upturn, economic downturn (crisis) and economic recovery. The number of immigrants, employment rate and population's density were identified as the major shadow economy determinants in Lithuanian regions. The determinants identified are unique in the case of Lithuania because they reveal that the labour market (employment rate, the number of immigrants) and population's density are the key factors that show how municipalities address the issues of the shadow economy. 10 municipalities with respectively high or low levels of the shadow economy were ranked for each period under consideration. The maps developed for different periods illustrate the general trends of the evolution of the shadow economy. This is the first study that estimates the size of the shadow economy in 60 municipalities (a small regional division) with different economic periods taken into account. Scientific novelty manifests through consideration of the regional shadow economy and proving significance of the labour market and immigration in reducing regional disparities.
\end{abstract}

Keywords: region shadow economy, the level of shadow economy in municipalities, MIMIC model, Lithuanian regions, municipalities, determinants of shadow economy.

JEL Classification: E26, C13, E24.

\section{Introduction}

Although scientific literature is rich in the research on different issues of the shadow economy, this topic is still relevant not only because it is primarily linked to unearned budget revenue, but also due to the fact that it distorts income distribution and determines misallocation of public resources.

${ }^{\star}$ Corresponding author. E-mail: rita.remeikiene@tf.vu.lt

Copyright (c) 2021 The Author(s). Published by Vilnius Gediminas Technical University

This is an Open Access article distributed under the terms of the Creative Commons Attribution License (http://creativecommons. org/licenses/by/4.0/), which permits unrestricted use, distribution, and reproduction in any medium, provided the original author and source are credited. 
While analysing the phenomenon of the shadow economy in the regional context, the questions can arise as to why and how regional shadow economy differs from the national shadow economy. Although regions, especially rural areas, still share a stereotypical image (in particular, in terms of cleaner environment), it should not be forgotten that many regions today are facing major challenges. Previous studies propose that foreign direct investment flows to regions are much less intensive than to cities, especially in the context of neoliberal globalization (Pick et al., 2010; Ramasamy et al., 2017; Li et al., 2018, etc.). Also, regions are forced to deal with such topical issues as the lack of attractive workplaces or workplaces in general (Williams, 2011), wage inequalities (Liu et al., 2011), aging society (Gadsby \& Samson, 2016) and unreasonable taxation policies (Li et al., 2014). As it was noted by Gadsby and Samson (2016), despite the fact that the above-mentioned problems have already been recognized for more than a decade, at present regions are approaching the threshold at which a shrinking tax base, an aging infrastructure and a rapidly declining population create the situation when regions can no longer maintain the basic level of services and infrastructure which are necessary to attract and sustain the population as well as businesses. There exists an interdependence between business (economic activities) and population: business is impossible without involvement of the population, while maintenance of the population is not possible without business conduct.

Gadsby and Samson (2016) state that sustainable development cannot be expected without maintaining a balance between urban and regional areas. This view is supported by Reimer (2004) who asserts that urban and regional economies are closely-related: regions supply urban areas with wood, food, minerals and energy that, in their turn, serve urban, and the same time, national economic growth. Thus, if regional economies renew and restore urban population, large shadow economies in regions impede national economic development (Weng, 2015). According to Medina and Schneider's (2017) approach, proposing that the shadow economy is caused by particular financial, regulatory and/or institutional determinants, it can be presumed that the likelihood of the shadow economy is much higher in regions than on a national scale.

Concerning the above-mentioned deep economic and social problems in regions, the main purpose of this article is to estimate the size of the shadow economy in Lithuanian regions. For fulfilment of the defined purpose, the following objectives were set: 1) to review previous scientific findings on the determinants of the shadow economy in regions; 2) to select and substantiate the methodology of the research; 3) to provide the results of the empirical research on the size and determinants of the shadow economy in Lithuanian regions. The methods of the research include comparative and systematic literature analysis, the MIMIC model.

In the first part of the article the theory of regional shadow economy and its determinants have been analysed. In the second part the empirical research methodology have been presented. In the third part of the paper the empirical results have been described. The article concludes with conclusions.

\section{Regional shadow economy and its determinants: theoretical background}

According to Gadsby and Samson (2016), regional economies are quite difficult to define because in many cases there are no formal boundaries between regions (e.g. in cases of ethnic regions), and population's affiliation to one or another region is largely determined 
intuitively. What inherent features could be employed to identify a particular region still remains a matter of discussions at both academic and political levels. The term "region" is not always related to the distance of the area from large cities, though this interpretation is also popular. Du Plessis et al. (2002) indicate that a regional area may also mean a separate social unit with its inherent population mentality, history and lifestyle. Summarising various interpretations, it can be stated that a regional area can be defined as an area with a smaller population and lower density than those in urban areas, which is remote from urban areas and possesses a specific identity as well as specific socio-cultural relationship.

According to quantitative proof of the hypothesis raised in Polovyan's (2015) study, the size of the shadow economy in a country is the sum of the shadow economies of its regions. Regional shadow economy can be affected by a variety of determinants. Previous findings concerning the main determinants of the shadow economy in regions are reviewed in Table 1.

Table 1. The review of some previous findings on the determinants of the shadow economy in regions (source: compiled by the authors)

\begin{tabular}{|c|c|c|c|}
\hline Author(s), year & Research method(s) & $\begin{array}{l}\text { Countries } \\
\text { and periods }\end{array}$ & Findings \\
\hline $\begin{array}{l}\text { Kireenko et al., } \\
2017\end{array}$ & $\begin{array}{l}\text { Factor analysis and } \\
\text { MIMIC modelling }\end{array}$ & $\begin{array}{l}\text { Russian } \\
\text { Federation } \\
\text { 2002-2013, } \\
\text { Ukraine } \\
\text { 2004-2013 } \\
\end{array}$ & $\begin{array}{l}\text { Shadow economy is determined by } \\
\text { demographic and criminogenic factors; } \\
\text { the impact of standard of living can vary } \\
\text { from country to country }\end{array}$ \\
\hline $\begin{array}{l}\text { Remeikiene et al., } \\
2018\end{array}$ & The MIMIC model & $\begin{array}{l}\text { Lithuania, } \\
\text { 2012-2016 }\end{array}$ & $\begin{array}{l}\text { Shadow economy is affected by } \\
\text { population's income, taxation, crime- } \\
\text { related determinants and particular } \\
\text { demographic factors }\end{array}$ \\
\hline $\begin{array}{l}\text { Kireenko and } \\
\text { Nevzorova, } 2019\end{array}$ & $\begin{array}{l}\text { Analysis of the } \\
\text { approximation } \\
\text { curves }\end{array}$ & $\begin{array}{l}\text { Russia, 2002- } \\
2013\end{array}$ & $\begin{array}{l}\text { The size of the shadow economy directly } \\
\text { correlates to the share of the agricultural } \\
\text { sector as percentage of GDP }\end{array}$ \\
\hline Gasiūnas, 2018 & The MIMIC model & $\begin{array}{l}\text { Europe, } \\
2010-2017\end{array}$ & $\begin{array}{l}\text { Shadow economy is mainly determined } \\
\text { by economic (GDP per capita, } \\
\text { unemployment rate), taxation (tax } \\
\text { burden, social protection expenditure) } \\
\text { and social (poverty risk, gender wage } \\
\text { gap) factors }\end{array}$ \\
\hline $\begin{array}{l}\text { Gonzalez-Fernan- } \\
\text { dez and Gonzalez- } \\
\text { Velasco, } 2015\end{array}$ & $\begin{array}{l}\text { Currency Demand } \\
\text { Approach }\end{array}$ & $\begin{array}{l}\text { Spain, 1987- } \\
2010\end{array}$ & $\begin{array}{l}\text { Shadow economy is to the greatest } \\
\text { extent affected by the personal income } \\
\text { tax }\end{array}$ \\
\hline $\begin{array}{l}\text { Prytula et al., } \\
2019\end{array}$ & $\begin{array}{l}\text { The MIMIC, expert } \\
\text { survey }\end{array}$ & $\begin{array}{l}\text { Ukraine, } \\
\text { 2000-2018 }\end{array}$ & $\begin{array}{l}\text { Main determinants of the shadow } \\
\text { economy include tax burden and social } \\
\text { protection, regulatory measures, the } \\
\text { quality of social services, the number of } \\
\text { self-employed }\end{array}$ \\
\hline Polovyan, 2015 & $\begin{array}{l}\text { Complex economic } \\
\text { and mathematical } \\
\text { models, based on } \\
\text { the major factors of } \\
\text { Doing Business }\end{array}$ & $\begin{array}{l}\text { Ukraine, } \\
\text { 2001-2012 }\end{array}$ & $\begin{array}{l}\text { Shadow economy is defined by the } \\
\text { reliability of right protecting institutions } \\
\text { and the level of the tax burden }\end{array}$ \\
\hline
\end{tabular}


End of Table 1

\begin{tabular}{|c|c|c|c|}
\hline Author(s), year & Research method(s) & $\begin{array}{l}\text { Countries } \\
\text { and periods }\end{array}$ & Findings \\
\hline Buček, 2017 & The MIMIC model & $\begin{array}{l}\text { The Czech } \\
\text { Republic, } \\
\text { 2005-2014 }\end{array}$ & $\begin{array}{l}\text { Shadow economy is determined by } \\
\text { labour market and number of people } \\
\text { with at least one distraint }\end{array}$ \\
\hline Buszko, 2017 & The MIMIC model & $\begin{array}{l}\text { Poland, 2006, } \\
2011 \text { and } \\
2016\end{array}$ & $\begin{array}{l}\text { The differences in the size of the shadow } \\
\text { economy in regions are determined by } \\
\text { the differences in regional economic } \\
\text { efficiency }\end{array}$ \\
\hline Bilonizhko, 2006 & The MIMIC model & $\begin{array}{l}\text { Russia, 2001- } \\
2003\end{array}$ & $\begin{array}{l}\text { Most significant shadow economy } \\
\text { determinants include tax pressure, } \\
\text { specialization and unemployment rate }\end{array}$ \\
\hline Vorobyev, 2015 & $\begin{array}{l}\text { Cross-section } \\
\text { regression model, } \\
\text { augmented } \\
\text { electricity dynamics } \\
\text { approach }\end{array}$ & $\begin{array}{l}\text { Russia, } \\
\text { 2004-2011 }\end{array}$ & $\begin{array}{l}\text { There exists high positive correlation } \\
\text { between the size of the shadow economy } \\
\text { and corruption, unemployment, and } \\
\text { especially dependency of regional } \\
\text { budget on Federal transfers }\end{array}$ \\
\hline Weng, 2015 & $\begin{array}{l}\text { Synthesis of } \\
\text { academic and grey } \\
\text { literature, conceptual } \\
\text { exploration, in-depth } \\
\text { case studies }\end{array}$ & $\begin{array}{l}\text { Sub-Saharan } \\
\text { Africa, } \\
\text { research } \\
\text { period not } \\
\text { indicated }\end{array}$ & $\begin{array}{l}\text { Shadow economy in regions is promoted } \\
\text { by customary rights and norms, } \\
\text { insufficient regulation and socio- } \\
\text { economic determinants }\end{array}$ \\
\hline $\begin{array}{l}\text { Williams and } \\
\text { Horodnic, } 2017\end{array}$ & $\begin{array}{l}\text { Face-to-face } \\
\text { interviews, multilevel } \\
\text { logistic regression } \\
\text { analysis }\end{array}$ & $\begin{array}{l}28 \mathrm{EU} \\
\text { member } \\
\text { states, } 2013\end{array}$ & $\begin{array}{l}\text { Costs of engaging in shadow work } \\
\text { outweigh the benefits, low perceived } \\
\text { penalties, low risk of detection and low } \\
\text { tax morale raise the size of the shadow } \\
\text { economy }\end{array}$ \\
\hline $\begin{array}{l}\text { Schwettmann, } \\
2020\end{array}$ & $\begin{array}{l}\text { Systematic literature } \\
\text { analysis, statistical } \\
\text { data analysis, in- } \\
\text { depth country case } \\
\text { studies }\end{array}$ & $\begin{array}{l}\text { Sub-Saharan } \\
\text { Africa, } 2020\end{array}$ & $\begin{array}{l}\text { The shadow economy is driven by } \\
\text { poverty, gender gaps, ethnicity, disability }\end{array}$ \\
\hline $\begin{array}{l}\text { Gillanders and } \\
\text { Parviainen, } 2018\end{array}$ & Enterprise Surveys & $\begin{array}{l}\text { Sub-Saharan } \\
\text { Africa, } \\
\text { Europe and } \\
\text { Central } \\
\text { Asia, Latin } \\
\text { America and } \\
\text { Caribbean, } \\
\text { 2006-2010 }\end{array}$ & $\begin{array}{l}\text { Corruption is strongly positively } \\
\text { correlated to the shadow economy at the } \\
\text { sub-national level }\end{array}$ \\
\hline $\begin{array}{l}\text { Davydova et al., } \\
2020\end{array}$ & $\begin{array}{l}\text { Systematic literature } \\
\text { analysis, critical } \\
\text { analysis }\end{array}$ & $\begin{array}{l}\text { Russia, } \\
\text { Irkutsk } \\
\text { region, } \\
\text { research } \\
\text { period not } \\
\text { indicated }\end{array}$ & $\begin{array}{l}\text { The informal economy is driven by } \\
\text { actor profits, insufficiency of regulation, } \\
\text { lack of governmental intervention, tax } \\
\text { burden }\end{array}$ \\
\hline
\end{tabular}


As it can be seen in Table 1, the determinants of the shadow economy may vary from region to region, although some general tendencies can be envisaged: many authors highlight the significance of taxation (Bilonizhko, 2006; Tafenau et al., 2010; Buehn, 2012; Polovyan, 2015; Gonzalez-Fernandez \& Gonzalez-Velasco, 2015; Gasiūnas, 2018; Remeikiene et al., 2018; Davydova et al., 2020), standard of living (Kireenko et al., 2017; Remeikiene et al., 2018), labour market (Bilonizhko, 2006; Tafenau et al., 2010; Buehn, 2012; Vorobyev, 2015; Buček, 2017; Prytula et al., 2019), institutional factors (Polovyan, 2015) and corruption (Vorobyev, 2015; Borlea et al., 2017; Gillanders \& Parviainen, 2018). Nevertheless, the results of some studies are contradictory, for instance, Buček's (2017) study found no evidence to prove the importance of particular types of taxes (e.g. corporate taxes).

Among all other factors, Buček (2017) observes that the labour market and the number of people with at least one distraint are statistically significant determinants of the shadow economy, while Vorobyev (2015) emphasizes the high positive correlation between the size of the shadow economy and dependency of regional budget on Federal transfers. Davydova et al. (2020) focus on insufficiency of regulation and a lack of governmental intervention and state that shadow activities in Russian regions are often hidden by authorities to gain financial benefits. Williams and Horodnic (2017) base their research on rational economic actor and social actor approaches and reveal that the size of the shadow economy in rural areas can be promoted by low perceived penalties, low risk of the shadow activity detection and low tax morale.

Kireenko's et al. (2017) research revealed that the main determinants of the shadow economy in Russia and Ukraine are the demographic factor and the criminogenic factor, although the impact of standard of living was found to be weaker in Russia, but stronger in Ukraine (the estimations exposed that formal employment in Russia weakly correlates to population's monetary income, while in Ukraine the correlation between these two factors is close). Remeikiene's et al. (2018) study confirmed that the size of the shadow economy is related to population's average income and the number of criminal offences. Apart from that, the impact of the share of indirect taxes, the cases of cigarette smuggling, population of women per 1000 men, the number of children in social risk families and the number of tourists was also detected. The significance of demographic factors was also confirmed by Schwettmann (2020) who argues that poverty, gender gaps, ethnicity and disability push most vulnerable social groups into the informal economy.

Gasiūnas (2018), who researched the level of the shadow economy in different European regions by employing the MIMIC model, found that the shadow economy in the northern European region is mainly affected by the proportion of the population at risk of poverty, expenditure on social protection and GDP per capita; the shadow economy in the eastern European region is significantly affected by expenditure on social protection and GDP per capita; the shadow economy in southern European region is to the greatest extent determined by unemployment rate, the proportion of the population at risk of poverty and tax burden; finally, the shadow economy in the western European region is mainly caused by the proportion of the population at risk of poverty and the gender wage gap. The differences observed among the regions in the countries under consideration propose that interdependence between various socio-economic determinants and the level of the regional shadow economy is 
conditioned by the gap in the elements constituting a country's economic and social system and ensuring its functioning. These findings are in line with the results provided by Weng (2015) who highlights significance of the role of socio-economic determinants. The author finds that the shadow economy in rural areas is driven by customary rights and norms (informal agricultural activities have historically been seen as legitimate), insufficient regulations to address the needs of rural actors, economic profit and demand from low-income consumers, and such social factors as poverty and income diversification.

It should be noted that unlike in urban territories, the size of the shadow economy in regions, in particular, in rural areas, can be significantly affected by the share of the agricultural sector in the total economy (or GDP). For instance, Kireenko and Nevzorova's (2019) study disclosed that there exists a direct correlation between the level of the shadow economy and the share of the agricultural sector as percentage of GDP in Russian regions. A noticeable correlation was identified between the size of the shadow economy and the share of rural population in the total population, while the correlation between the size of the shadow economy and the share of agriculture, hunting, and forestry in the GRP was found to be moderate. These findings can be explained by the fact that a substantial part of regional population, declining as a result of urbanization, are still dependent on agricultural activities (forestry, crop and livestock production, hunting, etc.), not efficient in terms of employment, although an increase in informal employment is as well observed in the non-agricultural sector.

There are manifold arguments to explain the differences observed in both the size of the shadow economy in regions and the determinants of the regional shadow economy. According to Buszko (2017), these differences are primarily determined by varying regional economic efficiency (Buszko, 2017). Bilonizhko (2006) puts the emphasis on specialization of a region - whether industrial or agricultural, while Polovyan (2015) links the differences to the factors of Doing Business, a region's economic structure and system-wide elements, such as property right, investor right protection or enforcement of contracts, that substantially affect the behaviour of economic agents.

Having compared the key determinants of the shadow economy identified by Schneider and Buehn (2016) with the determinants provided in Table 1, we can conclude that tax burden and institutional factors are the same affecting the shadow economy either at the national or regional level. Scientific studies that focus on regions as a smaller territorial unit provide more determinants of the shadow economy at the sub-national level. The major groups of these determinants include demographic (population of women per 1000 men; the number of children in social risk families) and criminogenic (the cases of cigarette smuggling; the number of criminal offences) factors. The number of tourists, share of the agricultural sector in rural territories and structure of regional budgets were also proved to be the determinants of the shadow economy.

On balance, much like the shadow economy at a national level, the shadow economy at a regional level is mainly affected by the determinants of taxation, standard of living, labour market, public institutions and corruption, although the impact of demographic and criminogenic factors should not also be underestimated. Since a substantial share of regional population are dependent on agricultural activities, the size of the shadow economy in regions can be significantly affected by the share of the agricultural sector in the total economy, 
which in not inherent to urban territories. The differences previous studies reveal in both the size and the determinants of the shadow economy in regions can be explained by varying regional economic efficiency, regional specialization, economic structure and system-wide factors, i.e. the gap in the elements constituting a region's economic and social system and ensuring its functioning.

\section{Research methodology}

MIMIC model, namely multiple indicators and multiple causes model is a special case of Structural Equation Modeling (Zellner, 1970; Hauser \& Goldberger, 1971). Structural Equation Modelling presents how sets of variables define latent variables and how these latent variables are related to each other applying regression, path and confirmatory factor analysis. Structural Equation Modelling estimates the parameters considering similarity between the sample covariance matrix which is calculated from data and the implied covariance matrix. The similarity between these matrices which is also a model fit criterion is evaluated using chi-square statistic.

MIMIC model consists of structural and measurement equation system. Structural model reflects the relationships between the latent variable $(\zeta)$ and observable causes $\left(X_{q}\right)$. Measurement model links the observable indicators $\left(Y_{p}\right)$ with latent variable. Frey and WeckHanneman (1984) are the first researchers that consider the size of the shadow economy as a "latent variable".

The latent variable, Shadow Economy, is linearly determined by exogenous causes and disturbance:

$$
\zeta=\alpha_{1} X_{1}+\alpha_{2} X_{2}+\ldots+\alpha_{q} X_{q}+\varepsilon
$$

Observable endogenous indicators are determined by latent variable and disturbances:

$$
\begin{gathered}
Y_{1}=\lambda_{1} \zeta+\varepsilon_{1} ; \\
Y_{2}=\lambda_{2} \zeta+\varepsilon_{2} ; \\
\cdots \\
Y_{p}=\lambda_{p} \zeta+\varepsilon_{p},
\end{gathered}
$$

where $\zeta$ is a latent variable (Shadow Economy), $\varepsilon$ is the structural disturbance and $\varepsilon_{i}$ corresponds to measurement errors. Since the SEM model and thus the MIMIC model is obtained based on the covariance matrix, it is important to investigate the existence of outliers, asymmetry and skewness that affect the covariance matrix.

When the studies that estimate the shadow economy in the literature are examined, it is seen that there is no method considered as the best. However, when the recent studies are examined, it is seen that studies estimating the shadow economy with MIMIC model are frequently used. It is an important advantage that the MIMIC model takes into account the multiple indicator and causal variables at the same time and allows prediction when estimation based on the maximum likelihood method. On the other hand, the MIMIC model has several disadvantages (Schneider \& Buehn, 2016; Giles \& Tedds, 2002; Helberger \& Knepel, 1988): The most common criticism is the fact that the MIMIC model is a confirmatory analysis, that 
is, it is not in an exploratory structure that examines which model is appropriate, and that the theoretical assumptions behind the selection of variables are required and this situation limits empirical studies. Another criticism is that the estimates lead to unstable coefficients depending on the sample size. However, the economic literature using the MIMIC model is aware of these limitations, but these limitations do not prevent the use of the MIMIC model in studies on shadow economy, on the contrary, these problems should encourage further research in this area (Schneider \& Buehn, 2016).

The dataset used in this study consists of annual observations between the years of 2001 and 2019 for 60 municipalities of Lithuania. The evaluated variables are partitioned into two groups, namely:

- Indicators: number of enterprises (NMR), number of beneficiaries (NB), municipality budget in total (TBUD), municipality budget for education (EBUD), municipality budget for social security (SBUD), municipality budget for health (HBUD). The above-mentioned parameters are selected as indicators taking into account that the level of the shadow economy should reduce the number of business enterprises, raise the number of beneficiaries, reduce the municipality budget in total as well as its separate components, i.e. budgets for education, social security and health.

- Causes: employment rate (EMP), unemployment rate (UNEMP), wages-salary (WAGE), population (POP), population density (POPD), immigration (IMM), emigration (EMI), number of nonfinancial corporation (FIN), number of pensioners beneficiaries (PEN), expenditures on benefits of families raising children (CHILD).

The theoretical reasons of the causes in the MIMIC model are as follows:

Employment rate. The higher is the shadow economy, the lower is employment rate, ceteris paribus (Medina \& Schneider, 2017).

Unemployment rate. The higher is unemployment rate, the higher is the probability to work in the shadow economy, ceteris paribus (Medina \& Schneider, 2017).

Wage. An increase in the minimum wage could create a competitiveness problem in the context of a relatively high level of informal economic activities in the long run; the empirical results, however, do not support any effect of an increase in the minimum wage in the short run (Davidescu \& Schneider, 2017).

Population / Population density. Densely populated areas tend to have lower levels of the shadow economy (Buček, 2017).

Immigration. Firstly, illegal immigrants are forced to work in the shadow economy. Secondly, many legal immigrants are employed in the low-skilled sector, where jobs are less secure and more likely to be irregular. Finally, the wider availability of illegal workers may concur to the establishment of a job-market equilibrium, which is more reliant on illegal work (Bosh \& Farre, 2013).

Although the impact of emigration, the number of non-financial corporations, the number of pensioners beneficiaries and expenditures on benefits of families raising children has not thus far been comprehensively researched in scientific literature, the authors of this article are of the opinion that the above-mentioned factors need to be considered. Emigration can be expected to raise the level of the shadow economy. The number of pensioners beneficiaries, in case they have addictive habits and their pensions are low, may engage in the consumption of smuggled goods and/or contribute to the pension through informal employment. Benefits 
for families raising children promote consumption; the income from these benefits can be spent in informal markets.

Data were obtained from Statistics Department of Lithuania and Employment Services Under the Ministry of Social Security and Labor of the Republic of Lithuania.

Indicator variables related with municipality budget and number of enterprises (NMR) are not available before the years 2004 and 2005, respectively. Due to these missing observations, potential effects of outliers and the aim of providing unbiased results the sample was split into three subsamples over the periods 2001-2006, 2007-2010 and 2011-2019. While determining these periods, the 2007 crisis was taken into consideration and divided into "pre-crisis", "crisis period", and "post crisis". Median values were obtained for each district over the relevant years for each period examined. The reason for using the median instead of the arithmetic mean is that the median values represents the data better in the presence of outliers.

Before employing the MIMIC model for each period, the presence of outlying observations that are inevitably encountered in the cross-sectional data and the existence of the multicollinearity problem, which is important in the selection of variables in the MIMIC model, were investigated. The presence of outliers in each variable was checked using boxplots. When all variables are considered, municipalities Vilnius city, Kaunas city, Klaipeda city, Panevezys city and Siauliai city are obtained as outlying observations in the dataset. Since the existence of outliers have effects on Pearson correlation matrix, the correlation values between indicators and between causes investigated using the robust weighted-MCD correlation matrix for the evaluation of multicollinearity. MCD is one of the high-breakdown estimator of covariance matrix which is resistant to outliers (Hubert \& Debruyne, 2010). According to robust MCD correlation matrix (Appendix), strong correlations which are above 0.8 can be summarized as follows: Between employment rate (EMP) with budget related variables (municipality budget in total (TBUD) - municipality budget for education (EBUD) municipality budget for social security (SBUD), POP, number of enterprises, CHILD and FINANCE, between POP with EMG, CHILD and FINAN, between EMIG and CHILD.

In MIMIC model, the assumption of Multivariate normality is essential for preserving the statistical properties of estimators. After the exclusion of the outlying municipalities from the dataset, "multivariate normality is confirmed by Mardia's test. Furthermore, in each MIMIC model, Mahalanobis distance squared values of observations confirmed the existence of multivariate normality as another indicator of normality assumption. ${ }^{1}$ Considering the high correlation values between causes, MIMIC model has been employed to each period. Table 2 only reports the results for MIMIC models which have better diagnostic statistics. As is known, small values of root mean square error of approximation (RMSEA, <0.05), large values of goodness of fit (GFI, >0.90) and comparative fit index (CFI, >0.90) indicate good model. During the evaluation process of models besides RMSEA, GFI and CFI diagnostics, "chi-square/ degrees of freedom" criteria is also evaluated. Chi-square test measures the fit of MIMIC model (null hypothesis is; covariance matrix of the predicted model and covariance matrix of the observed data are equal) however since chi square test is effected from

\footnotetext{
${ }^{1}$ MIMIC model calculations were also employed using robust covariance matrix in AMOS. The findings were similar to Table 2 .
} 
the sample size, the ratio chi-square value divided to degrees of freedom (less than 2 or 3 ) is accepted as an important indicator (Kline, 1998; Ullman, 2001).

\section{Results of empirical research}

The MIMIC models in Table 2 include the covariance between employment rate (EMP) and immigration (IMM). According to the model fit measures in Table 2, specification 1 and 2 provide satisfactory results for period 1 and period 2. For period 2, only specification 2 provides satisfactory results.

Period 1 - Pre Crisis

Specification 1: $\quad$ Shadow $=0.81^{\star} \mathrm{EMP}+0.34^{\star} \mathrm{IMM}+0.19^{\star} \mathrm{POPD}$

Specification 2: $\quad$ Shadow $=0.84^{\star} \mathrm{EMP}+0.39 \mathrm{IMM}$

Period 2 - Crisis

Specification 2: Shadow $=0.43^{\star} \mathrm{EMP}+0.83^{\star} \mathrm{IMM}$

Period 3 - Post Crisis

Specification 1: $\quad$ Shadow $=0.66 \mathrm{EMP}+0.37 \mathrm{IMM}+0.20 \mathrm{POPD}$

Specification 2: $\quad$ Shadow $=0.62 \mathrm{EMP}+0.43 \mathrm{IMM}$

Considering the models, it can be seen that employment rate (EMP), immigration (IMM) and population density (POPD) variables have a positive effect on the shadow economy. Since the coefficients are standardized, it is possible to compare the significance of the variables. According to this, it can be seen that the employment rate (EMP) has a more significant effect than immigration (IMM) in pre-and post-crisis periods, but in the crisis period, on the contrary, immigration (IMM) affects more significantly than the employment rate (EMP).

Although both model specifications above have yielded good results for period 1 and period 2 (since three periods are considered and compared in this study), instead of the specification containing the population variable, specification 2 whose variables are common in all three models was selected. The models based on specification 2 were used for three periods while examining the shadow economy in each municipality.

As can be seen from Table 2, WAGE variable does not appear to have a significant effect on the shadow economy when all three periods are taken into account. Although the population density (POPD) variable appears to have a statistically significant effect for the pre-and post-crisis periods, this is not valid for the crisis period. Logarithms of budgetrelated variables are included in this model. However, due to the strong correlation values of municipality budget in total (TBUD) and municipality budget for education (EBUD) with number of enterprises, Specification 1 was preferred instead of 2. As a matter of fact, the values in Table 3 and Table 4 were also obtained based on Specification 2.

Considering three periods, it can be said that over time employment rate (EMP) shows an U shaped development, whereas immigration (IMM) shows inverse U shaped development.

The impact of the Shadow economy on number of enterprises (NMR) post-crisis and during the crisis is greater than before the crisis. However, the impact of the Shadow economy on variable number of beneficiaries (NB) increased in the post-crisis period. In all three periods, number of enterprises (NMR) and number of beneficiaries (NB) variables appear to be positively influenced by Shadow economy. 


\begin{tabular}{|c|c|c|c|c|c|c|c|c|c|c|c|c|c|c|c|c|c|c|}
\hline \multirow{4}{*}{ 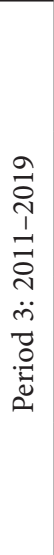 } & H & & 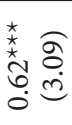 & 음 & 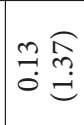 & 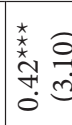 & & 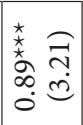 & 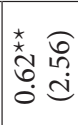 & & 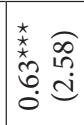 & & & ণָ & $\begin{array}{l}H \\
\infty \\
\infty \\
0\end{array}$ & 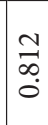 & $\begin{array}{l}\vec{\sigma} \\
\dot{r}\end{array}$ & 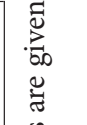 \\
\hline & $m$ & & 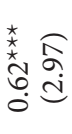 & 1 & $\begin{array}{l}m \stackrel{\sigma}{a} \\
\stackrel{n}{0} \stackrel{n}{=}\end{array}$ & 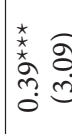 & & 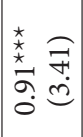 & 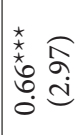 & 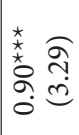 & & & & 告 & ॠ' & 市 & 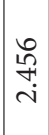 & 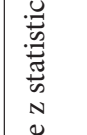 \\
\hline & $N$ & & 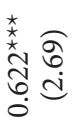 & & & 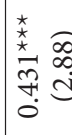 & & 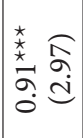 & 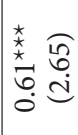 & & & & & $\begin{array}{l}\overrightarrow{0} \\
\stackrel{0}{0}\end{array}$ & 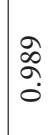 & $\vec{\sigma}$ & 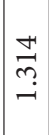 & 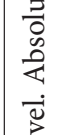 \\
\hline & $\neg$ & & 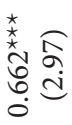 & 1 & 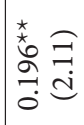 & 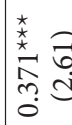 & & 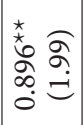 & 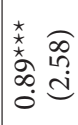 & & & 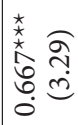 & & 它 & 文 & $\begin{array}{l}\vec{\infty} \\
\stackrel{a}{0}\end{array}$ & $\underset{\widetilde{Z}}{\tilde{\sim}}$ & $\begin{array}{l}\stackrel{0}{a} \\
\stackrel{1}{ \pm} \\
=\end{array}$ \\
\hline \multirow{4}{*}{ 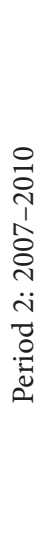 } & F & & 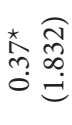 & 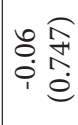 & 象 & 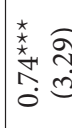 & & 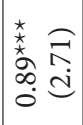 & 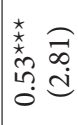 & & 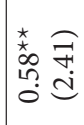 & & & 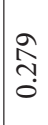 & $\stackrel{\hat{N}}{\hat{乏}}$ & 寺 & $\underset{\sim}{\stackrel{\overbrace{}}{\leftrightarrows}}$ & 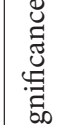 \\
\hline & $m$ & & 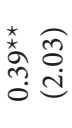 & 1 & 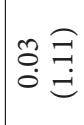 & 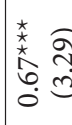 & & 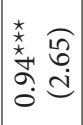 & 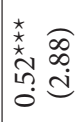 & 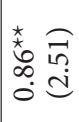 & 1 & & & $\begin{array}{l}+ \\
0 \\
\\
0\end{array}$ & $\begin{array}{l}\pi \\
\infty \\
\infty \\
0\end{array}$ & $\begin{array}{l}\widetilde{Z} \\
\infty \\
0 \\
0\end{array}$ & $\begin{array}{l}\bar{\lambda} \\
\text { in }\end{array}$ & 苞 \\
\hline & $\sim$ & & 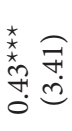 & 1 & & 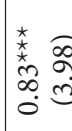 & & 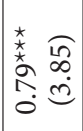 & 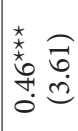 & & & & & 홍 & 命 & ఫे & 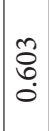 & 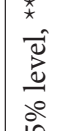 \\
\hline & - & & 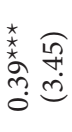 & 1 & $\begin{array}{ll}n & \widehat{a} \\
0 & \hat{\sigma}\end{array}$ & 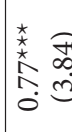 & & 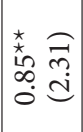 & 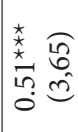 & & & $\begin{array}{ll}\star & \widehat{\sigma} \\
\pi & \stackrel{0}{0} \\
0 & =\end{array}$ & & $\frac{m}{2}$ & $\begin{array}{l}- \\
\infty \\
\infty \\
0\end{array}$ & $\begin{array}{l}\stackrel{2}{\partial} \\
\infty \\
0\end{array}$ & $\frac{\infty}{a}$ & 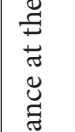 \\
\hline \multirow{4}{*}{ 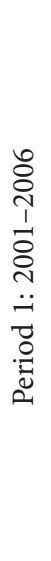 } & 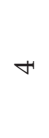 & & 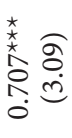 & 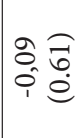 & 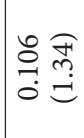 & 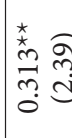 & & 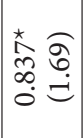 & 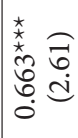 & & 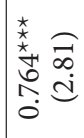 & 1 & & 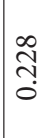 & $\begin{array}{l}\text { } \\
\infty \\
\infty \\
0\end{array}$ & $\stackrel{N}{N}$ & $\underset{H}{\vec{H}}$ & 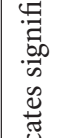 \\
\hline & $m$ & & 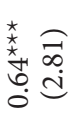 & 1 & $\begin{array}{ll}a & \widehat{\partial} \\
0 & \infty \\
0 & 0\end{array}$ & 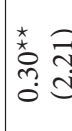 & & 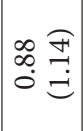 & 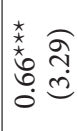 & 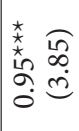 & 1 & & & సָ & $\begin{array}{l}\stackrel{1}{0} \\
\infty \\
0 \\
0\end{array}$ & $\begin{array}{l}\text { U } \\
\infty \\
0 \\
0\end{array}$ & $\begin{array}{l}\overrightarrow{0} \\
\text { in } \\
\text { in }\end{array}$ & 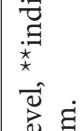 \\
\hline & $N$ & & 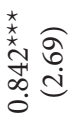 & 1 & & 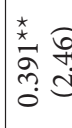 & & 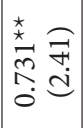 & 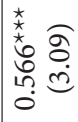 & 1 & 1 & 1 & & 官 & 䒘 & $\begin{array}{l}\infty \\
0 \\
0 \\
0\end{array}$ & $\stackrel{l}{\circ}$ & 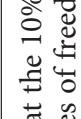 \\
\hline & - & & 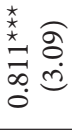 & 1 & 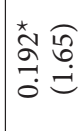 & 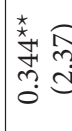 & & 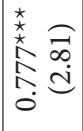 & 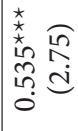 & & & 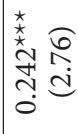 & & 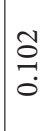 & के & ڤે & 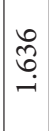 & 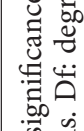 \\
\hline م. & 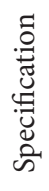 & 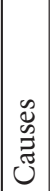 & $\sum_{\mid=1}^{B}$ & 鬲 & 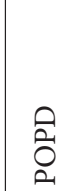 & $\sum_{\vdots}$ & 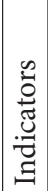 & $\sum_{Z}^{\mathscr{n}}$ & 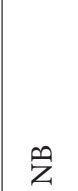 & 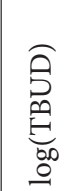 & $\begin{array}{l}\widehat{\rho} \\
\overbrace{0}^{\infty} \\
\stackrel{0}{0} \\
0\end{array}$ & 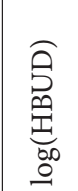 & 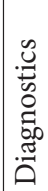 & 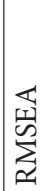 & 岕 & 密 & 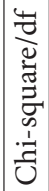 & 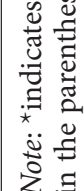 \\
\hline
\end{tabular}


Table 3. Municipalities with the 10 smallest shadow economies

\begin{tabular}{|l|c|c|l|c|c|l|c|c|}
\hline \multicolumn{2}{|c|}{ First Period (2001-2006) } & \multicolumn{2}{c|}{ Second Period (2007-2010) } & \multicolumn{2}{c|}{ Third Period (2011-2019) } \\
\hline & Median & SD & & Median & SD & & Median & SD \\
\hline Kazlų Rūdos & 16,495 & 5,746 & Molètų & 17,542 & 7,119 & Birštono sav. & 10,485 & 3,525 \\
\hline Kupiškio & 17,183 & 7,154 & Elektrènų & 18,800 & 4,505 & Varėnos r. & 11,532 & 3,324 \\
\hline Kalvarijos & 17,600 & 5,107 & Zarasų raj. & 19,745 & 9,587 & Akmenès raj. & 11,552 & 3,474 \\
\hline Neringos & 17,934 & 8,135 & Lazdynų raj. & 19,987 & 7,243 & Rietavo & 11,777 & 3,791 \\
\hline Akmenės raj. & 18,500 & 21,517 & Pakruojo raj. & 20,070 & 6,275 & Pagègių & 12,661 & 3,007 \\
\hline Birštono sav. & 18,857 & 6,797 & Silalès & 20,131 & 2,959 & Zarasų raj. & 12,676 & 3,666 \\
\hline Panevěžio & 20,180 & 4,250 & Anyǩ̌čių & 20,554 & 3,541 & Rokiškio & 12,776 & 3,531 \\
\hline Palangos & 20,188 & 9,745 & Biržų raj. & 20,744 & 3,687 & Šakių raj. & 13,032 & 3,545 \\
\hline Skuodo & 20,374 & 13,361 & Kauno r. & 23,495 & 9,044 & Utenos raj & 13,249 & 3,321 \\
\hline Pagėgių & 20,376 & 7,640 & Telšių raj. & 23,638 & 3,681 & Kazlų Rūdos & 13,593 & 3,105 \\
\hline
\end{tabular}

Note: ${ }^{\star S D}$ : Standard Deviation. ${ }^{\star}$ Base years considered are 2004, 2009, 2014.

Table 4. Municipalities with the 10 largest shadow economies

\begin{tabular}{|l|c|c|l|c|c|l|c|c|}
\hline \multicolumn{2}{|c|}{ First Period (2001-2006) } & \multicolumn{2}{c|}{ Second Period (2007-2010) } & \multicolumn{3}{c|}{ Third Period (2011-2019) } \\
\hline & Median & SD & & Median & SD & & Median & SD \\
\hline Jonavos r. & 25,950 & 3,451 & Jonavos r. & 29,467 & 10,862 & Kretingos & 17,630 & 3,677 \\
\hline Šakių raj. & 25,953 & 12,604 & Visagino & 29,483 & 10,723 & Kalvarijos & 17,630 & 5,173 \\
\hline Kauno r. & 26,861 & 5,523 & Kaišiadorių & 29,528 & 7,776 & Šiaulių m. & 17,767 & 11,341 \\
\hline Kretingos & 27,000 & 11,646 & Plungès raj. & 30,142 & 10,625 & Šiaulių raj. & 17,944 & 12,608 \\
\hline Klaipėdos m. & 27,089 & 1,708 & Klaipėdos m. & 30,488 & 12,261 & Jonavos r. & 18,385 & 2,943 \\
\hline Druskininkų & 27,140 & 6,525 & Neringos & 30,822 & 5,261 & Šalčininkų & 19,140 & 9,619 \\
\hline Lazdynų raj. & 27,582 & 7,095 & Kretingos & 32,115 & 9,058 & Klaipėdos & 19,611 & 17,304 \\
\hline Vilniaus m. & 31,140 & 2,852 & Ukmergès r. & 32,980 & 8,340 & Elektrènų & 19,692 & 25,749 \\
\hline Zarasų raj. & 32,254 & 4,773 & Šalčininkų & 33,598 & 13,147 & Neringos & 20,665 & 13,291 \\
\hline Rietavo & 33,051 & 6,748 & Širvintų & 35,329 & 18,283 & Kupiškio & 21,308 & 5,420 \\
\hline
\end{tabular}

Note: ${ }^{\star}$ SD: Standard Deviation. ${ }^{\star}$ Base years considered are 2004, 2009, 2014.

Considering the relevant MIMIC models (specification 2), for each period, the level of the shadow economy in percentage of GDP values for 60 municipalities was obtained by using Schneider's et al. (2010) formula:

$$
\hat{\eta}_{t}=\frac{\hat{\eta}_{t}}{\hat{\eta}_{2004}} \hat{\eta}_{2004}^{*},
$$

where $\hat{\eta}_{t}$ denotes the value of the MIMIC index at $\hat{\eta}_{2004} t$; is the value of this index in the base year 2004. The other base years are 2009 and 2014. The same formula was used by Nchor (2021). Due to the unique economic structure of each period, the calculations of the level of the shadow economy in percentage of GDP are based on the three base years that 
were extracted from an exogenous estimate (Medina \& Schneider, 2017). Based on these calculations, Table 3 and Table 4 present the 10 smallest and 10 largest shadow economies respectively. Tables 3-4 also include the median and standard deviation values calculated over the respective years for each municipality. The reason for using the median instead of the arithmetic mean is the excessive fluctuations observed in some years for some municipalities (especially in 2017, 2018 and 2019). The immigration variable, which describes the Shadow Economy latent variable, explains the fluctuation in these years. For example, immigration in Elektrenai municipality in 2019 increased by $407 \%$ compared to 2015 . Median is a type of average that is resistant to such kinds of fluctuations.

The large standard deviation values indicate that the changes in the series, in other words, the fluctuations, are high. Table 3 indicates that the standard deviation for Akmenes is 21.52, although Akmenes is in the list of those municipalities with the lowest shadow economy values. This situation can be explained by the increase in the immigration to Akmenes by $176 \%$ in 2005 compared to 2004. Silales is the least fluctuating municipality during the crisis period. As seen in Table 4, Elektrenai, one of the municipalities with the highest shadow economy in the third period, also has the highest standard deviation value. Elektrenai, however, is the second municipality with the lowest shadow economy during the crisis. Considering the fact that the shadow economy values for Lithuania in the base years were 25.65 (in 2004), 24.29 (in 2009) and 17.62 (in 2014) respectively, and leaning on Medina and Schneider's (2017) calculations, it is seen that all municipalities in Table 4 are above the base year values. A striking point in the above-mentioned tables is that the shadow economy values in the third period are lower than those in the previous two periods.
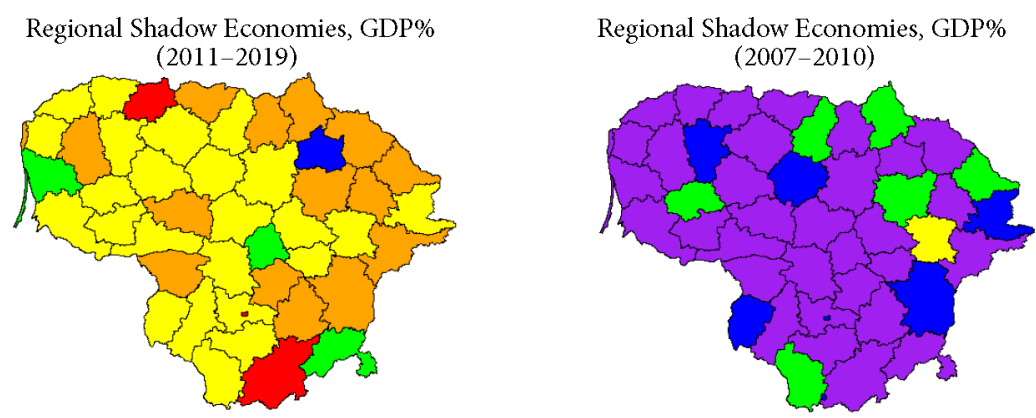

Regional Shadow Economies, GDP\% (2001-2006)

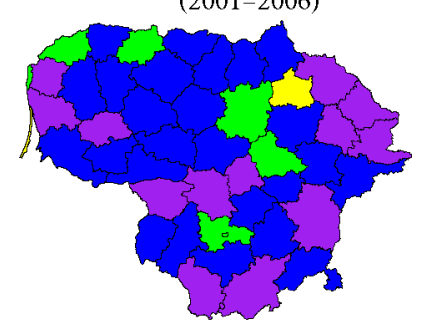

\begin{tabular}{ll|} 
Red: & $<=12$ \\
Orange: & $12.01-15$ \\
Yellow: & $15.01-18$ \\
Green: & $18.01-21$ \\
Blue: & $21.01-25$ \\
Purple: & $25.01+$
\end{tabular}

Figure 1. Maps of the regional shadow economies for three periods (own calculation) 
As can be seen from Figure 1, while the levels of the shadow economies in most of the municipalities are between 21 and 25 in the period before the crisis, they are mostly larger than 25 during the crisis period. Nevertheless, the municipalities with the levels of the shadow economies between 15 and 18 are tended to have the highest rates after the crisis.

\section{Conclusions}

Summarising, it can be concluded that in the context of this study, the level of the shadow economy for Lithuanian municipalities over three periods under consideration - economic upturn (2001-2006), economic crisis (2007-2010) and economic recovery (2011-2019) - has been estimated for the first time. The number of immigrants, employment rate and population's density were identified as the major shadow economy determinants in Lithuanian municipalities. All the determinants affected the level of the shadow economy in all regions in a single direction which was either positive or negative. Thus far, scientific research has hardly considered the impact of official immigration; it has mainly focused on the negative impact of unofficial immigration on "the shadow" in the labour market. The finding that employment rate also raises the level of the shadow economy encourages the authors to delve into the causes of employment, for instance, envelope wages, cheating on the taxes paid on employees, etc. The empirical estimations have revealed that the worst situation could be observed during the crisis period when the highest levels of the shadow economy were recorded in Širvintų, Šalčininkų, Ukmergès and Kretingos district municipalities (the level of the shadow economy amounted to 32-35 percent of GDP).

The results of this research can be useful to the public institutions (municipalities, the Employment Service, Immigration Department) that are responsible for promoting regional socio-economic development by reducing the size of the shadow economy in particular municipalities. Further research on this issue can address the causes pushing the unemployed to get involved into the informal labour market as a structural part of the shadow economy with consideration of the role smuggling cigarettes and other excisable goods.

\section{Funding}

This work was supported by Lithuanian Research Council under Grant [S-GEV-20-3].

\section{Author contributions}

All authors contribution is equal.

\section{Disclosure statement}

Authors do not they have any competing financial, professional, or personal interests from other parties. 


\section{References}

Bilonizhko, O. (2006). Measurement and determinants of the hidden economy in regions of Ukraine and Russia: MIMIC approach. http://www.kse.org.ua/uploads/file/library/2006/bilonizhko.pdf

Borlea, S., Achim, M. V., \& Miron, M. G. A. (2017). Corruption, shadow economy and economic growth: an empirical survey across the European Union countries. Studia Universitatis Economic Series, 27(2), 19-32. https://doi.org/10.1515/sues-2017-0006

Bosh, M., \& Farre, L. (2013). Immigration and the informal labour market (Discussion paper, no. 7843). IZA. http://ftp.iza.org/dp7843.pdf

Buček, J. (2017). Determinants of the shadow economy in the Czech regions: a region-level study. Review of Economic Perspectives, 17(3), 315-329. https://doi.org/10.1515/revecp-2017-0016

Buehn, A. (2012). The shadow economy in German regions: an empirical assessment. German Economic Review, 13(3), 275-290. https://doi.org/10.1111/j.1468-0475.2011.00557.x

Buszko, A. (2017). The level of shadow economy in Warminsko-Mazurski and Kujawsko-Pomorski regions. Copernican Journal of Finance \& Accounting, 6(4), 9-21. https://doi.org/10.12775/CJFA.2017.020

Davidescu, A. A., \& Schneider, F. (2017). Nature of relationship between minimum wage and the shadow economy size: an empirical analysis for the case of Romania (Discussion paper series IZA DP, No. 11247). IZA. http://ftp.iza.org/dp11247.pdf

Davydova, G., Tagiev, M., Tagiev, I., \& Ryabinina, E. (2020). Shadow economy in logging activities (on the example of the Irkutsk region). Baikal Research Journal, 11(4), 1-8. https://doi.org/10.17150/2411-6262.2020.11(4).11

Du Plessis, V., Beshiri, R., Bollman, R. D., \& Clemenson, H. (2002). Definitions of "rural". https://ageconsearch.umn.edu/bitstream/28031/1/wp020061.pdf

Frey, B., \& Weck-Hanneman, H. (1984). The hidden economy as an "unobservable" variable. European Economic Review, 26(1), 33-53. https://doi.org/10.1016/0014-2921(84)90020-5

Gadsby, L., \& Samson, R. (2016). Strengthening rural Canada. Why place matters in rural communities. https://www.decoda.ca/wp-content/uploads/Strengthening-Rural-Canada_Final.pdf

Gasiūnas, U. (2018). Šešèlinès ekonomikos lygio vertinimas Europos regioniniu aspektu [Shadow economy estimation at the European regional level] [Master's Final Thesis]. Mykolas Romeris University, Vilnius.

Giles, D. E. A., \& Tedds, L. M. (2002). Taxes and the Canadian underground economy (Canadian Tax Paper, Vol. 106). Canadian Tax Foundation, Toronto.

Gillanders, R., \& Parviainen, S. (2018). Corruption and the shadow economy at the regional level. Review of Development Economics, 22(4), 1729-1743. https://doi.org/10.1111/rode.12517

Gonzalez-Fernandez, M., \& Gonzalez-Velasco, C. (2015). Analysis of the shadow economy in the Spanish regions. Journal of Policy Modelling, 37(6), 1049-1064. https://doi.org/10.1016/j.jpolmod.2015.09.006

Hauser, R. M., \& Goldberger, A. S. (1971). The treatment of unobservable variables in path analysis. In H. L. Costner (ed.), Sociological methodology (pp. 81-117). Jossey-Bass. https://doi.org/10.2307/270819

Helberger, C., \& Knepel, H. (1988). How big is the shadow economy? A re-analysis of the unobserved-variable approach of B.S. Frey and H.Weck-Hannemann. European Economic Review, 32(4), 965-976. https://doi.org/10.1016/0014-2921(88)90055-4

Hubert, M., \& Debruyne, M. (2010). Minimum covariance determinant. WIREs Computational Statistics, 2, 36-43. https://doi.org/10.1002/wics.61 
Kireenko, A., Ivanov, Y., Nevzorova, E., \& Polyakova, O. (2017). Shadow economy in the regions of the Russian Federation and the Ukraine. https://doi.org/10.1007/978-3-319-49559-0_28

Kireenko, A., \& Nevzorova, E. (2019). Shadow economy in the countryside of Russian regions. Regional Research of Russia, 9, 66-77. https://doi.org/10.1134/S2079970519010052

Kline, R. B. (1998). Methodology in the social sciences. Principles and practice of structural equation modeling. Guilford Press.

Li, Y., Wang, J., Liu, Y., \& Long, H. (2014). Problem regions and regional problems of socio- economic development in China: a perspective from the coordinated development of industrialization, informatization, urbanization and agricultural modernization. Journal of Geographical Sciences, 24(6), 1115-1130. https://doi.org/10.1007/s11442-014-1142-y

Li, Z., Li, J., \& He, B. (2018). Does foreign direct investment enhance or inhibit regional innovation efficiency? Evidence from China. Chinese Management Studies, 12(1), 35-55. https://doi.org/10.1108/CMS-02-2017-0034

Liu, H., Chen, Y., \& Long, H. (2011). Regional diversity of peasant household response to new countryside construction based on field survey in Eastern costal China. Journal of Geographical Sciences, 21(5), 869-881. https://doi.org/10.1007/s11442-011-0886-x

Medina, L., \& Schneider, F. (2017). Shadow economies around the world: new results for 158 countries over 1991-2015 (CESifo Research Paper No. 6430). America. https://papers.ssrn.com/sol3/papers.cfm?abstract_id $=2965972$

Nchor, D. (2021). Shadow economies and tax evasion: The case of the Czech Republic, Poland and Hungary. Society and Economy, 43(1), 21-37. https://doi.org/10.1556/204.2020.00029

Pick, D., Dayaram, K., \& Butler, B. (2010). Regional development and global capitalism: the case of the Pilbara, Western Australia. Society and Business Review, 5(1), 99-110. https://doi.org/10.1108/17465681011017282

Polovyan, O. V. (2015). Evaluation of shadow economy size in region. Economy of Industry, 1(69), 53-64. https://doi.org/10.15407/econindustry2015.01.053

Prytula, K. M., Shults, S. L., Samilo, A. V., \& Masiov, V. O. (2019). The magnitude and nature of the shadow economy in Ukrainian border regions. Financial and Credit Activity: Problems of Theory and Practice, 4(31), 394-401. https://doi.org/10.18371/fcaptp.v4i31.190958

Ramasamy, M., Dhanapal, D., \& Murugesan, P. (2017). Effects of FDI spillover on national productivity: Evidence from panel data analysis using stochastic frontier analysis. International Journal of Emerging Markets, 12(3), 427-446. https://doi.org/10.1108/IJoEM-11-2015-0246

Reimer, B. (2004). Exploring diversity in rural Canada. Measuring Rural Diversity Policy Series, 1(2), $1-7$.

Remeikiene, R., Rozsa, Z., Gaspareniene, L., Chadysas, V., \& Ginevicius, R. (2018). Regional estimates of shadow economy in Lithuania. Engineering Economics, 29(4), 386-396. https://doi.org/10.5755/j01.ee.29.4.19438

Schneider, F., Buehn, A., \& Montenegro, C. E. (2010). New estimates for the shadow economies all over the world. International Economic Journal, 24(4), 443-461. https://doi.org/10.1080/10168737.2010.525974

Schneider, F., \& Buehn, A. (2016). Estimating the size of the shadow economy: Methods, problems and open questions. (IZA Discussion Papers 9820). Institute of Labor Economics (IZA).

Schwettmann, J. (2020). COVID-19 and the informal economy. http://library.fes.de/pdf-files/iez/16414.pdf

Tafenau, E., Herwartz, H. \& Schneider, F. (2010). Regional estimates of the shadow economy in Europe. International Economic Journal, 24(4), 629-636. https://doi.org/10.1080/10168737.2010.526010

Ullman, J. B. (2001). Structural equation modeling. In B. G. Tabachnick \& L. S. Fidell (Eds.), Using multivariate statistics. Pearson Education. 
Vorobyev, P. (2015). Estimating informal economy share in Russian regions (Working Paper No. E15/02, pp. 1-45). Economics, Education and Research Consortium.

Weng, X. (2015). The rural informal economy. Understanding drivers and livelihood impacts in agriculture, timber and mining. http://pubs.iied.org/pdfs/16590IIED.pdf

Williams, C. C. (2011). Entrepreneurship, the informal economy and rural communities. Journal of Enterprising Communities: People and Places in the Global Economy, 5(2), 145-157. https://doi.org/10.1108/17506201111131578

Williams, C. C., \& Horodnic, I. A. (2017). Tackling the participation of Europe's rural population in the shadow economy. https://www.redalyc.org/pdf/296/29650532001.pdf

Zellner, A. (1970). Estimation of regression relationships containing unobservable variables. International Economic Review, 11, 441-454. https://doi.org/10.2307/2525323 


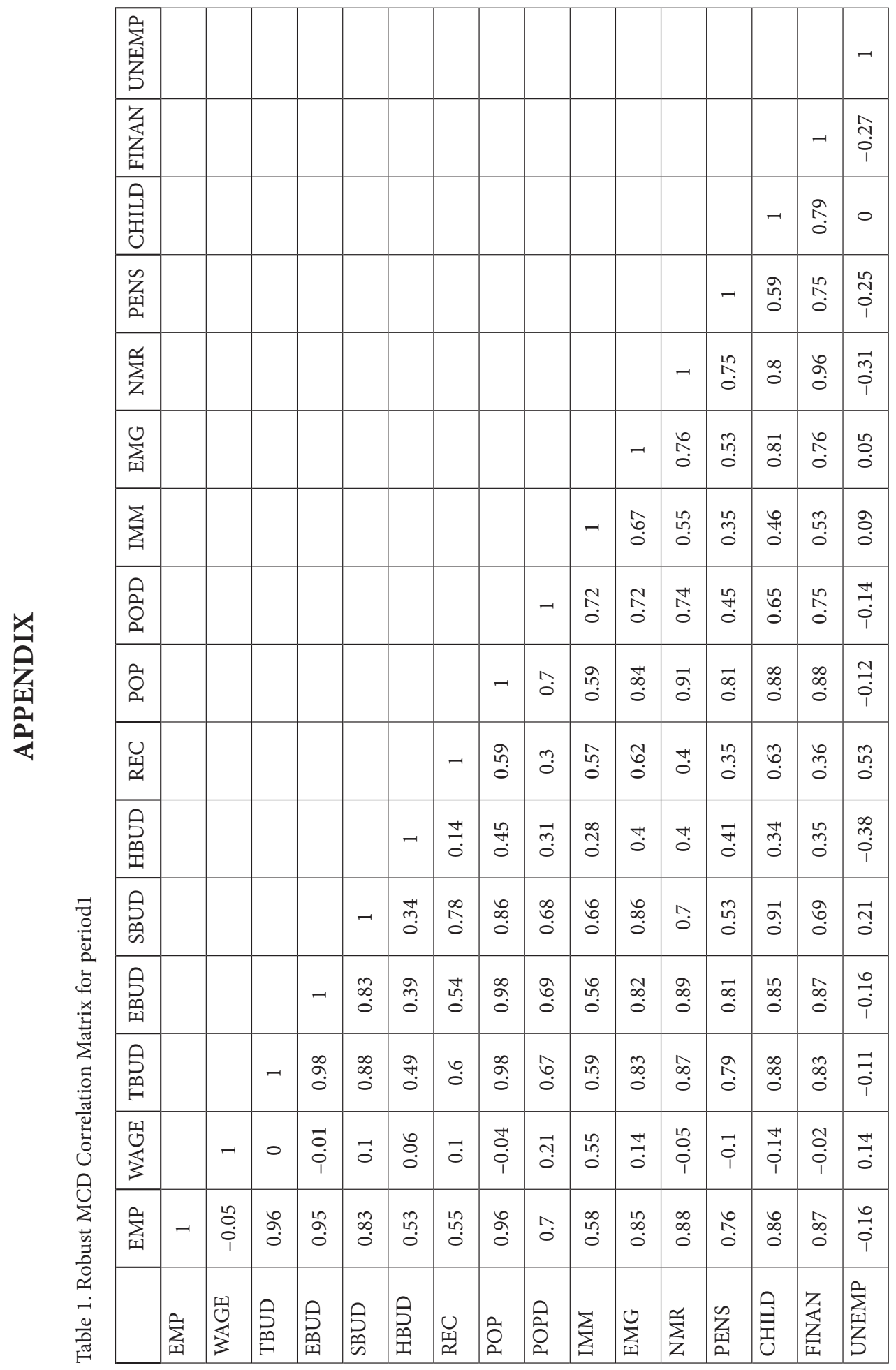

